\title{
Development of Literacy Through a Combination Picture and Picture Learning Models, Singing Methods and Scondhand Material
}

\author{
Dahliana *, Ali Racman, Aslamiah \\ ${ }^{1}$ Master Program of Early Childhood Teacher Education, Universitas Lambung Mangkurat, Banjarmasin 70123, \\ Indonesia \\ ${ }^{2}$ Program Counseling Education, Universitas Lambung Mangkurat, Banjarmasin 70123, Indonesia
}

\section{Article history:}

Submission August 2020

Revised September 2020

Accepted September 2020

*Corresponding author:

E-mail: dahliana123@gmail.com

\begin{abstract}
This study is to describe the teachers' activities and children and improve the development of early childhood literacy skills through a combination of picture and picture models and singing methods with used media. This research uses the Classroom Action Research (CAR) method. Research settings in group B children in Sayang Ibu kindergarten Cukan Lipai, Batang Alai Selatan District, Hulu Sungai Tengah Regency, amounting to 16 children in the 2019/2020 school year, consisting of 15 boys and six girls. Data collection techniques using observation, documentation, and interviews and assessment of aspects of cognitive development. Indicators of the success of teacher activities score 27-32 with an outstanding category, children's activities reach $\geq 82 \%$ (very active) and the development of children's literacy of at least $80 \%$ of children or get a $3 \operatorname{star}(\star \star \star)$ with the category of developing in line with expectations (BSH). Conclusion of the results of the study: teacher activity reached $97 \%$ outstanding results of children's activities classically $82 \%$ very active category and the results of children's literacy development $94 \%$ reached $\star \star \star$ developing as expected and $\star \star \star \star$ developing very well.
\end{abstract}

Keywords:Literacy, picture and image, singing, secondhand material

\section{Introduction}

Children are the successors of the nation's struggle. They will one day develop this nation and country (Izadkhah \& Hosseini, 2005), while to become a developed and competent nation, development in the field of education is needed, one of which is quality education. Early Childhood Education mainly organized, facilitating the growth and development of children as a whole or emphasizing the development of all aspects of the child's personality. By providing stimuli for physical, spiritual (moral and spiritual), motoric, reasoning, emotional, and socially appropriate and correct, the child develops optimally (Sujiono, 2013).

Kindergarten Education is a form of early childhood education that plays an essential role in developing children's personalities (Sandseter,
2014). Kindergarten education is an intermediary that connects the family environment with the broader community, namely primary schools and other environments (Heikka \& Waniganayake, 2011). As one form of early childhood education, this institution provides an early education program for at least four-year-old children to enter the primary education level. According to (Suriansyah \& Aslamiah, Education Foundation, 2011), Kindergarten Education is a form of early childhood education that has a vital role in developing children's personalities and preparing them to enter the next level of education.

Early childhood is at the golden age. In that phase can develop all the potential it has with a variety of games (Edward \& Cutter-Mackenzie, 2013). One of the abilities of a child developing at 
the age of kindergarten, according to the 2013 Curriculum is the language ability, which consists of three parts: receiving language and expressing language and literacy (Maba, 2017). What is included in language development are listening, reading, speaking, and writing (Renukadevi, 2014). Language is a form of communication of interaction between parents and children, teachers and children and with others (Harrigan \& Nikopoulos, 2002). Communication is an activity of everyone wherever he is because communication is one of the needs of humans as social beings (Castells, 2007). Communication can be said to be the heart of life in organizations. Without communication, the organization will die; at least it cannot optimally develop because it states communication is a key to successful team effort (Suriansyah \& Aslamiah, 2011). One form of communication is the ability to speak with functional language (Oradee, 2012). The ability to speak is the ability to say articulation sounds or words to express, express, convey thoughts, ideas, and feelings felt by children.

Children's language development from when they are born until the age of six (0-6) years is a golden period and is very important. According to (Hildayani, 2004) states the development of language skills for AUD aims for children to communicate verbally. Language is a human tool to express our thoughts and feelings to others (Dewaele, 2011). The most intensive period of children's speech and language development in humans lies in the first three years of their lives, a period in which the human brain develops in the process of reaching maturity. Children's language skills are obtained from family, neighbors, school, and playmates (Purwanti, Aslamiah, Suriansyah, \& Dalle, 2018). When conducting this research, the teacher found many benefits. Including being able to understand that children will be more active when children are directly involved in these activities, the use of exciting media will foster children's attention by directly training them to gain their own experience (Chen, Chou, Deng, \& Chan, 2007). The use of teaching media also help young learners to understand the learning materials better (Dalle, Hadi, Baharuddin, \& Hayati, 2017). Early childhood education teachers should provide the students with well-scaffolded instruction that can support the students' social development, emotional, academic, habits, and mindsets
(Darling-Hammond, Flook, Cook-Harvey, Barron, \& Osher, 2020). A teacher is expected to provide an excellent environment to foster student development optimally in the learning process (Suriansyah A. , Aslamiah, Noorhafizah, \& Sulaiman, 2009).

How to learn early childhood is different from the way of learning adults and older children (Skarstein \& Skarstein, 2020), namely through playing and using media tools such as touching, building and breaking down, filling and emptying, stringing, listening to stories and singing, playing roles, etcetera. Learning in kindergarten is carried out with the principle of "learning while playing" per the development of students. At the age of 4-6 years, children are still in playtime so that all activities carried out in kindergarten prioritize play activities (Abril, 2006). With learning activities while playing, students are expected to develop all their abilities (Chow, Woodford, \& Maes, 2011).

The Minister of Education and Culture Regulation of the Republic of Indonesia Number 137 of 2014 concerning Early Childhood Education Standards in the scope of language development is literacy in children aged 4-6 years (Ministry of Education and Culture, 2014). Pre-literacy or early literacy is a term used to describe a child's ability to use literacy, reading, and writing that is mastered before a child learns how to read and write (Al-Qaryouti \& Kilani, 2015).

Education in kindergartens has been introduced alphabetically from a to $\mathrm{z}$. In the process of introducing early literacy, especially for group Children (ages 4-5 years) in kindergarten. Early literacy recognition learning is by introducing vowels and consonants, which are the basis of reading. Through the introduction of vowels and consonants, children will understand the shape of letters and form individual syllables and words (Charlton, Williams, \& McLaughlin, 2005). In optimizing its implementation, children need to be guided by teachers so that children's abilities in literacy will increase (Perry \& VandeKamp, 2000). It is in line with the opinion (Metroyadi \& Mardhiah, 2018) that another factor that supports the development of children's learning outcomes is the ability of teachers to deliver learning material that motivates and can coordinate children in the classroom. Educators should be able to create a new learning atmosphere so that children are not bored and fed up when receiving learning. He uses 
of current technology can be a good idea in making the learning activities more fun (Baharuddin \& Dalle, 2017). Besides, language skills are also in the character values developed through the curriculum at school (Ulla \& Winitkun, 2017). What the teacher teaches is the school's result and will be accepted by students and then sent to parents (Suhaimi \& Rinawati, 2018).

Many people are still pros and cons of introducing early literacy or teaching reading and writing to early childhood. Some claim that reading and writing at the age of children before elementary school means forcing children to have abilities that should have been taught in elementary school (Sunde, Furnes, \& Lundetrae, 2020). It results in playtime, which should be the dominant activity in their age. It will be reduced or even neglected, so it is feared that it will hamper the development of children's potential and abilities optimally in the future. Others think it is okay to teach reading and writing from an early age. Usually, those who have opinions to allow children to be taught to read and write are motivated so that their children do not experience difficulties when entering elementary school. The demand to enter elementary school now requires that children can read and write (Davidson \& Hobbs, 2013).

Learning literacy in early childhood is very important because introducing early literacy means instilling a reading culture from an early age. Reading one way to transfer knowledge from print and electronic media and reading a lot of means will add insight and open and get to know the horizons of the world (Dorouka, Papadakis, \& Kalogiannakis, 2020). Therefore, reading culture needs to be developed.

The most important thing for developing literacy in children is how to teach it to children so that children perceive their learning activities as playing and even in the form of an exciting game (Beschorner \& Hutchison, 2013). So, activities or learning to know literacy in kindergarten can be carried out while still within the limits of the rules and the characteristics of children, namely learning while playing (Aulia, 2011). The role of teachers and parents is significant in children's development, especially in understanding the golden age of children as early as possible (Baiti, Metroyadi, \& Wahyu, 2019). It shows that when conducting research, the teacher will find many benefits. Including teachers can understand that children will be more active when children are directly involved in these activities. The use of new media will foster children's attention by directly training the child and getting his own experience. Becoming the teacher not only tells the activity, but the child immediately does it so that the instilling of the independent attitude that the teacher wants to achieve can run optimally (Safitri, Ahmad, \& Saleh, 2018).

Based on observations or observations of researchers in the first semester of the academic year 2019/2020 on August 29, 2019, in group B Sayang Ibu Kindergarten, the ability (achievements of children) in recognizing literacy is still low. The introduction of literacy with a total of 16 children, namely 0 children, gets the category of Very Good Developing (BSB) with a percentage of $0 \%$. Five children get the category of Starting to Develop (MB) and Develop according to expectations also five children with a percentage $31.25 \%$ each and six children received the Underdeveloped (BB) category with a percentage of $37.5 \%$ in literacy recognition. When teachers ask questions in literacy recognition activities, there are only two children who can answer almost right. Some children are shy about answering questions or being passive. Some children are less interested and preoccupied with their activities. Some are joking with friends that it interferes with the concentration of other friends who are watching or following the learning activities provided by the teacher.

It happens because children feel bored or bored in class; this saturation occurs because the activities carried out are still abstract and unattractive. Therefore, researchers provide alternative learning strategies with picture and picture models, used materials, and singing methods to create atmosphere learning activities that become more concrete and make children interested. The use of these models and methods is done with a playful concept. It is expected to stimulate children to say and understand words or sentences intended to improve language skills and be more interested in recognizing literacy. It also functions to train the cognitive, affective, and psychomotor development of children. According to Kurniasih and Sani (2014), the Picture and Picture Model is a cooperative learning model that uses picture media to be paired or sorted into logical sequences. This learning model relies on images as concrete media in the development process. This picture is the main 
factor in achieving development indicators. Images are critical to clarifying understanding and understanding. Through images, children will be more interested and know things that they have never seen. In addition, the use of pictures can encourage the students to engage during the teaching and learning process (Purwanti, Suriansyah, Aslamiah, \& Dalle, 2018). The method of singing that the researchers chose was to remember that early childhood loved doing activities while singing (Bolduct, 2009). Then the used materials that exist in the child's environment so that children easily recognize them, mainly to introduce literacy to children.

The results of observations and explorations conducted by researchers so far in Sayang Ibu Kindergarten Cukan Lipai, Batang Alai Selatan District, show that literacy is one part of children's language development is still lacking. Low literacy skills in early childhood should be of particular concern. The learning model, teaching media, and methods provided by the teacher are less attractive to children's learning interests and are less effective in developing children's literacy abilities.

Based on the occurrence problem, the researcher wants to examine and need to research to find out about models, methods, and learning media, which are appropriate for developing early childhood literacy abilities. It is to find out the activities of teachers, children's activities, and the results of the development of literacy skills in the children of Group B Sayang Ibu Kindergarten Cukan Lipai, Batang Alai Selatan District, Hulu Sungai Tengah Regency.

\section{Material and Methods}

Classroom Action Research (CAR) is an effort that teachers can do to improve the quality of teachers' roles and responsibilities, especially in the management of learning. CAR is part of the teacher's professional ability. CAR is a scientific activity that is a systematic and empirical thought process to solve a problem that is the problem of the teacher's learning process himself in carrying out the main task of teaching (Sanjaya, 2013).

The study was conducted at Sayang Ibu Kindergarten, located in Cukan Lipai Village, RT 01 RW 01, Batang Alai Selatan District, Hulu Sungai Tengah Regency. The study's subject was class B, amounting to 16 people consisting of 5 girls and 11 boys. This class action research procedure was carried out in two cycles, each cycle consisting of two meetings. Each meeting includes four stages: planning, implementation, observation and reflection (Kemmis \& McTaggart, 1992).

Data analysis is through the activities of teachers, children, and the results of children's language development. Indicators of success in this research are considered successful if the activities of teachers reach $82-100 \%$ with top categories, children's activities reach $80-100 \%$ with very active categories and on the results of the development of children's literacy abilities if classically $\geqslant 80 \%$ recognize the symbol get a minimum gets $\star \star \star$ (Develops as Expected) and $\star \star \star \star$ (Develops Very Well).

\section{Results and Discussion \\ Teacher's activity}

The teacher's activity in the development of children's literacy was by the steps that had been planned and were carried out in the first cycle and obtained a percentage of $78.13 \%$ in the top category. Then in the second cycle increased to a percentage of $81.25 \%$ still in the excellent category. Furthermore, in the third cycle again increased with the acquisition of a percentage of $87.5 \%$ in the top category but still needs to be developed and improved because it has not yet obtained optimal results. In the fourth cycle, teacher activity increased again with a percentage of $96.9 \%$ and top category. So, the activities of teachers in literacy development can be said to succeed in achieving the desired category.

The teacher is an individual who deals directly with students through a process of instructional interaction as a vehicle for the learning process (Aslamiah, 2011). According to Suriansyah et al. (2009), a teacher is expected to be able to provide an excellent environment to be able to foster students' development optimally in the learning process. The learning by the teacher runs optimally because the teacher at each meeting always makes reflections so that from the reflection the teacher knows the deficiencies that should not be done at the next meeting, the teacher also masters the learning model better so that the learning carried out runs optimally (Olteanu, 2016).

Learning also does not escape from the teacher's role in providing learning material to children (Allana, Asad, \& Sherali, 2010). The role of teachers helps children acquire communication skills, 
solve problems, and resolve conflicts (Suriansyah \& Aslamiah, 2011).

Rusman (2012) states that activities in the classroom are marked by the presence of classroom management activities, the use of media and learning resources, and the use of learning methods and strategies, all of which require the teacher's ability in their implementation. It is in line with the opinion (Sanjaya, 2013) that the teacher of a planner before carrying out the process of activities in the classroom must prepare what material to be conveyed, how to convey it, and what media is suitable for use.

In selecting models, methods, and learning media, a teacher must also consider the extent to which all of these things that will be used can enhance the development of children's literacy abilities individually and not only consider the aspects of the group. Because learning is to make children can achieve the desired goals. Developing each child's personality in achieving learning is a goal that should be considered in determining the learning strategies that will be used (Suriansyah \& Aslamiah, 2011).

The Picture and picture model is a cooperative learning model or prioritizes the existence of groups using picture media that are paired or sorted into a logical sequence. This learning model relies on images as media images in the development process (Zhai, Jocz, \& Tan, 2014). These images are the main factors to achieve development indicators (Kurniasih \& Sani, 2016).

In this study, researchers used pictorial media, pictorial media included in the type of pictorial media, because pictorial is a more contextual learning medium and can develop the potential of children's literacy abilities optimally, which is the focus of the researcher. Used media in the form of images is included in the visual media group, which is media that only relies on the sense of sight. Compared to audio media, visual media in certain situations is far better as a learning medium (Buchori \& Setyawati, 2015). Especially for young children. By using his vision, a child will know precisely about something he learned. In this case, the pictures relating to letters or literacy. Literacy development can also through singing methods (Ginting, 2020). Playing in kindergarten through singing is a fun activity and is very popular and is done early in daily activities (Bulunuz, 2012). A song or a song can have an impact on someone. For children, the song will influence the growth and development of values that can change attitudes towards maturity. Besides, the song can also provide motivation, interest, and talent in singing. By singing, children not only express thoughts and feelings, but also can increase knowledge in this case about letters or literacy, entertain or create an atmosphere of joy, and control the emotional aspects.

Singing has proven to be an ideal tool for young children to learn in a fun way and be the best tool for teaching language to young children. Thus it can be concluded that based on theories that support teacher activity shows improvement. It occurs because teachers always make improvements every implementation at meetings held and always make efforts to improve the implementation of the next cycle meeting because teachers feel not satisfied with the results obtained if seen from the expectations and goals to be achieved by the teacher. Therefore, the teacher's activity increases much better each meeting and gets a perfect classification. The teacher knows the characteristics that must be possessed, preparing material planning, media, and methods to be used, and the teacher mastering the steps of a combination of picture and picture models, used materials, and singing methods that are well implemented.

In this case, the picture (media picture and picture) is significant to clarify understanding. Through images, the child knows things he has never seen and is more exciting and more concrete. Before starting the activity, the teacher has prepared a picture that will be displayed in the form of letter cards or in the form of objects that match the theme-created from used materials to train children to recognize and develop literacy skills interspersed with singing so that learning becomes enjoyable. Besides, the teacher can manage the class well and directed so that the teacher's activities get results very well or very well and satisfying.

\section{Children's activities}

Children's activities in early childhood literacy development have been carried out well with the achievement of children's activities, including the category of less active and quite active individually shown in the table reaching $43.75 \%$ or seven children and $52.25 \%$ or eight children. Then in the next cycle, the increase can be seen in that eight 
children or $52.25 \%$ of children are quite active and seven children or $43.75 \%$ of active children's activities. Likewise, with the next cycle or cycle III, children's activity also increased again, namely 13 children or $81.25 \%$ active, one child or $6.25 \%$ were quite active, and two children or $12.5 \%$ started to be very active. In the last cycle or cycle IV, there was an increase in 3 children or $18.75 \%$ with active category and 13 children or $81.25 \%$ with a very active category.

There has been an increase in each cycle, so children's literacy skills development activities have reached success indicators. Children's activities in each cycle show a significant increase. In these learning activities can increase children's learning activities due to a combination of learning than usual. Models, media, and learning methods serve as a bridge between teachers and children in improving learning outcomes so that learning objectives are essential for learning models, methods, and media. In other words, the maximum benefit can be expected from the learning objectives to be achieved or a very close relationship. The purpose of media development as an effort to motivate or encourage learners themselves, consciously or not so that it can influence the learning process.

Many media have a positive impact on children concerning the process of developing the brain and about children's activities. It will be easier for teachers to bring children to enjoy the development of the material provided or learning activities that are being carried out. Knowledge and basic concepts are much easier to obtain through play activities because the attention span of children under five is still limited. Besides, they are more challenging to manage.

Literacy learning is part of reading through a combination of pictures and picture models. Use materials and singing methods per the nature of learning in kindergarten. Because the nature of early childhood learning presented in the CBC, one of which is that lessons must be per characteristics of early childhood which are actively exploring in play activities, the learning process activities are emphasized on children's activities in the forms of learning while playing (Singer, 2013). Based on the theory that supports, the increase in children's activity occurs because of the teacher's accuracy in making improvements in each cycle in the development of literacy skills. Through a combination of picture and image, materials and singing methods are used, namely by motivating children not to be embarrassed to answer teacher questions, motivating them to be confident and responsible in completing the tasks given.

Motivation, which is full of attention and affection from the teacher, makes the children no doubt and no longer ashamed of doing or completing activities. If seen from the characteristics of early childhood, active and energetic, the children are happy and happy to do activities such as singing. Singing activities will create a pleasant classroom atmosphere. Other characteristics of children are intense curiosity and enthusiasm for many things, exploratory and adventurous, and shortsighted. However, with the media and singing activities, children become more interested and happy in participating in various learning activities. Children increasingly show interest in other friends, from collaborative activities (sorting pictures), the child relates to other friends so that the child begins to show to collaborate with others.

\section{The results of literacy skills development}

Children's abilities in developing early childhood literacy skills through a combination of pictures used materials, and singing methods in group B Sayang Ibu Kindergarten, Batang Alai Selatan District, Hulu Sungai Tengah Regency, was developed and well implemented. It shown in each cycle carried out.

The results of the development of learning abilities are the impressions that result in changes in the individual as a result of learning activities. Learning achievement is the result of a teacher's assessment of children's progress after learning activities. The function of learning is not only to know the extent of the child's progress after carrying out activities but, more importantly, is as a tool to motivate each child to be active in learning both individually and in groups (Djamarah, 2014). The development of children's literacy development abilities through a combination of pictures, use pictorials, and singing methods in group B Kindergarten Sayang Ibu was initially only about $25 \%$ of children who can get a three-star. After learning through the used material media, both individually and classically, can increase. Of the four cycles of the implementation of learning the development of 
children's literacy ability, there is always an increase, from the first cycle of children who have three and four stars only as much as $75 \%$ and after the fourth cycle even more to reach $90.6 \%$. This achievement has exceeded the indicators of success that have been determined before increasing the development of children's literacy abilities.

Children are central subjects with the potential, talents, and interests that must be developed by other parties. The atmosphere must be lovingly, safely, meet the basic needs of children, get stimulation and opportunities, and great opportunities to be helped by other family members to develop the abilities and interests of the child (Sujiono, 2013). Early childhood learning through active learning, the method used is to give questions to children and let them think, ask themselves, so the learning outcomes obtained are the results of the child's construction (Sujiono, 2013). Because children can build and create their knowledge, so children must be directly involved in the learning process. Learning experiences in children are gained more by playing, experimenting with real objects, and through actual experiences. Children get the opportunity to create and manipulate objects or ideas.

Based on the theory above, children can create their knowledge, so it is crucial to involve children directly in developing literacy skills. Activities carried out through children's experiences by playing to arrange letters, sort pictures, and sing. Because the child is an active learner, the child will absorb all the information that comes to him either intentionally given by people around the child or accidentally found by children (Abante, Almendral, Manansala, \& Manibo, 2014). So that through the combination of the Picture and picture model, the used materials and singing methods increase in each cycle, both of the children's activities and the children's ability to develop literacy.

With learning through the method of singing, the influence on language development (literacy) children may be more effective (Hallam, 2010) because singing is a fun activity that is loved by children (Young, 2008). The singing method is a learning method that uses symphonic poems (Fadlillah, 2012). Singing makes the learning atmosphere cheerful and excited so that the child's language development (literacy) can be optimally stimulated. Singing may increase vocabulary that children's language development (literacy) can develop optimally (Corcoll, 2013). Because singing makes the learning atmosphere enjoyable so that children's activities and the results of the development of children's literacy skills also increase both from cycle I to the next cycles.

Table 1. Comparison of results from observations of teacher activity, child activity, and child development outcomes

\begin{tabular}{ccccc}
\hline & \multicolumn{2}{c}{ Cycle I } & \multicolumn{2}{c}{ Cycle I } \\
$\begin{array}{c}\text { Develop- } \\
\text { ment }\end{array}$ & $\begin{array}{c}\text { Meeting } \\
I\end{array}$ & $\begin{array}{c}\text { Meeting } \\
\text { II }\end{array}$ & $\begin{array}{c}\text { Meeting } \\
\text { III }\end{array}$ & $\begin{array}{l}\text { Meet- } \\
\text { ing IV }\end{array}$ \\
\hline $\begin{array}{c}\text { Teachers } \\
\text { Activity }\end{array}$ & $78.13 \%$ & $81.25 \%$ & $87.5 \%$ & $96.9 \%$ \\
$\begin{array}{c}\text { Child Ac- } \\
\text { tivity }\end{array}$ & $43.75 \%$ & $52.25 \%$ & $81.25 \%$ & $99 \%$ \\
$\begin{array}{c}\text { Develop- } \\
\text { ment Out- } \\
\text { comes }\end{array}$ & $25 \%$ & $31.25 \%$ & $75 \%$ & $90.6 \%$ \\
\hline
\end{tabular}

\section{Conclusion and Recommendation}

The combination of picture and picture learning models, singing methods, and used materials media could develop and improve literacy skills of group B children in Sayang Ibu Kindergarten, Batang Alai Selatan District, Hulu Sungai Tengah Regency in the academic year 2019/2020. It proven from the pre-cycle results before applying a combination of picture and picture learning models, used materials, and singing methods $29.5 \%$ have not met the KKM increase in the first cycle, which shows that students reach the classical completeness criteria 75\% (11 students who complete). In comparison, in cycle II the classical completeness criteria were $90.6 \%$ (14 students who completed). Thus the learning outcomes obtained by students from cycle I to cycle II increased by $15.6 \%$. Therefore, the class action researcher (CAR) was declared victorious. It especially welcomed by the children's parents and the surrounding community who wanted their children able to read and write, but the way they were delivered or in their implementation the teacher must hold the principle of learning in early childhood, namely "Learning through playing and playing while learning".

Recommendation for further researchers to develop the PAUD curriculum's scope of development that uses a combination of models, methods, and more learning media to provide new 
knowledge for the world of early childhood education, especially in kindergarten institutions (Samuelsson, Sheridan, \& Williams, 2006).

\section{Acknowledgment}

Thanks to the head of the program, the secretariat, and the lecturers of the Master of Teacher Education Program in Early Childhood Education at Lambung Mangkurat University, Banjarmasin, who have provided input and suggestions for writing this article. Furthermore, thanks to the educators and education staff at Sayang Ibu Kindergarten, Cukan Lipai, Batang Alai Selatan District, Hulu Sungai Tengah Regency, who have helped with the smooth running of this research. May we all always be in the Blessing of Allah SWT. Amen.

\section{References}

Abante, M. R., Almendral, B. C., Manansala, J. E., \& Manibo, J. (2014). Learning styles and factors affecting the learning of general engineering students. International Journal of Academic Research in Progressive Education and Development, 3(1), 16-27.

Abril, C. R. (2006). Learning outcomes of two approaches to multicultural music education. International Journal of Music Education, 24(1), 30-42.

Al-Qaryouti, I. A., \& Kilani, H. A. (2015). Role of Omani parents: fostering emergent literacy skills. International Journal of Primary, Elementary and Early Years Education, 43(3), 336348.

Allana, A., Asad, N., \& Sherali, Y. (2010). Gender in Academic Settings: Role of Teachers . International Journal of Innovation, Management and technology, 1(14), 343-348.

Aslamiah. (2011). Application of habituating children's behavior through learning and playing activities in Al-Hamid Kindergarten Banjarmasin. Paradigm Journal, 5(10), 33-44.

Aulia. (2011). Teaching your children to read: Smart revolution for children's reading skills at home. Yogyakarta: Intan Media.

Baharuddin, \& Dalle, J. (2017). Interactive Coursewear for Supporting Learners Competency in Practical Skills. TOJET: The Turkish Online Journal of Educational Technology, 16(3), $1-3$.

Baiti, N., Metroyadi, \& Wahyu. (2019). Parenting, socio-economic, and parental communication against children's language ability. j-K6EM, 2(1), 58-63.

Beschorner, B., \& Hutchison, A. C. (2013). iPads as a literacy teaching tool in early childhood part of the communication technology and new media commons, curriculum and instruction commons, elementary education and teaching commons, and the higher education commons. International
Journal of Education in Mathematics, Science and Technology, 1(1), 16-24.

Bolduct, J. (2009). Effects of a music programme on kindergartners' phonological awareness skills. International Journal of Music Education, 27(1), 37-47.

Buchori, A., \& Setyawati, R. D. (2015). Development learning model of character education through e-comic in elementary school. International Journal of Education and Research, 3(9), 369386.

Bulunuz, M. (2012). Developing turkish preservice preschool teachers' attitudes and understanding about teaching science through play. International Journal of Environmental and Science Education, 72(2), 141-166.

Castells, M. (2007). Communication power and counter-power in the network society. International journal of communication, 1(2007), 238-266.

Charlton, B., Williams, R. L., \& McLaughlin, T. F. (2005). Educational games: a technique to accelerate the acquisition of reading skills of children with learning disabilities. International Journal of Special Education, 20(2), 66-72.

Chen, Z. H., Chou, C. Y., Deng, Y. C., \& Chan, T. W. (2007). Active open learner models as animal companions: motivating children to learn through interacting with my-pet and our-pet. International Journal of Artificial Intelligence in Education, 17(2), 145-167.

Chow, A., Woodford, K., \& Maes, J. D. (2011). Deal or no deal: using games to improve student learning and retention. International Journal of mathematical Education in science and Technology, 42(2), 259-264.

Corcoll, C. (2013). Developing children's language awareness: switching codes in the language classroom. International Journal of Multilingualism, 10(1), 27-45.

Dalle, J., Hadi, S., Baharuddin, \& Hayati, N. (2017). The Development of Interactive Multimedia Learning Pyramid and Prism for Junior High School Using Macromedia Authorware. TOJET: The Turkish Online Journal of Educational Technology, 2017(Special Issue), 714-722.

Darling-Hammond, L., Flook, L., Cook-Harvey, C., Barron, B., \& Osher, D. (2020). Implications for educational practice of the science of learning and development. Applied Developmental Science, 24(2), 97-140. doi:https://doi.org/10.1080/10888691.2018.1537791

Davidson, M., \& Hobbs, J. (2013). Delivering reading intervention to the poorest children: the case of Liberia and EGRA-Plus, a primary grade reading assessment and intervention. International Journal of Educational Development, 33(3), 283-293.

Dewaele, J. M. (2011). Reflections on the emotional and psychological aspects of foreign language learning and use . International Journal of English studies, 22(1), 23-42. 
Djamarah, S. (2014). Parenting and communication patterns in the family. Jakarta: Rineka Cipta.

Dorouka, P., Papadakis, S., \& Kalogiannakis, M. (2020). Tablets and apps for promoting robotics, mathematics, STEM education and literacy in early childhood education. International Journal of Mobile Learning and Organisation, 14(2), 255-275.

Edward, S., \& Cutter-Mackenzie, A. (2013). Pedagogical play types: what do they suggest for learning about sustainability in early childhood education? International Journal of Early Childhood, 45(3), 327-346.

Fadlillah, M. (2012). Early childhood education learning design, theoretical \& practice review. Jakarta: Ar-Ruzz Media.

Ginting, M. B. (2020). Improving the memory through singing method of children ades 5-6 yarsa in kirdergarten Insan Pandhega. International Journal of Emerging Issues in Early Childhood Education, 1(2), 93-110.

Hallam, S. (2010). The power of music: Its impact on the intellectual, social and personal development of children and young people. International Journal of Music Education, 28(3), 269-289.

Harrigan, S., \& Nikopoulos, T. P. (2002). Parent interaction course in order to enhance communication skills between parent and children following pediatric cochlear implantation. International Journal of Pediatric Otorhinolaryngology, 66(2002), 161-166.

Heikka, J., \& Waniganayake, M. (2011). Pedagogical leadership from a distributed perspective within the context of early childhood education. International Journal of Leadership in Education, 14(4), 499-512.

Hildayani, R. (2004). Development Psychology. Jakarta: Universitas Terbuka.

Izadkhah, Y. O., \& Hosseini, M. (2005). Towards resilient communities in developing countries through education of children for disaster preparedness. International Journal of Emergency Management, 2(3), 138-148.

Kemmis, S., \& McTaggart, R. (1992). The action research planner. Victoria: Deakin University.

Kurniasih, I., \& Sani, B. (2014). Implementation of the 2013 curriculum, concept \& application. Surabaya: Kata Pena.

Kurniasih, I., \& Sani, B. (2016). Instructional Method. Yogyakarta: Kata Pena.

Maba, W. (2017). Teacher's perception on the implementation of the assessment process in 2013 curriculum. International Journal of Social Science and Humanities, 1(3), 1-9.

Metroyadi, \& Mardhiah, A. (2018). Efforts to develop children fine motor skills through sticking picture properly using combination of explicit instruction model and assignment media utilizing natural materials. J-K6EM, 1, 22.

Ministry of Education and Culture. (2014). The rules of the minister of education and culture of Indonesia Republic No 137 of 2014 about early childhood education curriculum. Jakarta: Ministry of education and culture.
Olteanu, C. (2016). reflection and the object of learning. International Journal for Lesson and learning studies, 5(1), 60-75.

Oradee, T. (2012). Developing speaking skills using three communicative activities (discussion, problem-solving, and role-playing). International Journal of Social Sciences and Humanity, 2(6), 533-535.

Perry, N. E., \& VandeKamp, K. O. (2000). Creating classroom context that support young children's development of selfregulated learning. International Journal of Educational Research, 33(7-8), 821-843.

Purwanti, R., Aslamiah, Suriansyah, A., \& Dalle, J. (2018). Introducing language aspects (english)to early childhood through the combination of picture and picture model, talking stick model, flashcard media, and movement and song method in B1 group at Matahariku Bbilingual kindergarten Landasan Ulin Tengah. Eropean Jurnal of Education Studies, 5(7), 4863.

Purwanti, R., Suriansyah, A., Aslamiah, \& Dalle, J. (2018). Childhood through the combination of picture and picture model, talking stick model, flashcard media, and movement and song method in B1 group at Matahariku Bilingual Kindergarten Landasan Ulin Tengah Banjarbaru, Indonesia. European Journal of Education Studies, 5(7), 26-34. doi:10.5281/zenodo. 1494188

Renukadevi, D. (2014). The role of listening in language acquisition; the challenges $\&$ strategies in teaching listening. International Journal of Education and Information Studies, 4(1), 59-63.

Rusman. (2012). Learning models developing teacher professionalism. Jakarta: PT Raja Grafindo Persada.

Safitri, M. E., Ahmad, K., \& Saleh, M. (2018). Development Of Child Independence Through Model Picture and Picture, Examples Non-Examples Model and Practical Method Directly Activities of Learning Practical Life In Group B Kasih Ibu Kindergarten, Banjarmasin, Indonesia. European Journal of Education Studies, 5(7), 36-48.

Samuelsson, I. P., Sheridan, S., \& Williams, P. (2006). Five preschool curricula-comparative perspective. International Journal of Early Childhood, 38(1), 11-30.

Sandseter, E. H. (2014). Early childhood education and care practitioners' perception of children's risky play; examining the influence of personality and gender . Early Child Development and Care, 184(3), 434-449.

Sanjaya, W. (2013). The Education Process Standart Oriented Learning Strategy. Jakarta: Prenada.

Singer, E. (2013). Play and playfulness, basic features of early childhood education. European Early Childhood Education Research Journal, 21(2), 172-184.

Skarstein, T. H., \& Skarstein, F. (2020). Curious children and knowledgeable adults-early childhood student-teachers' species identification skills and their views on the importance 
of species knowledge. International Journal of Science Education, 42(2), 310-328.

Suhaimi, \& Rinawati, Y. (2018). Management of character education curriculum at vocational high school 2 Kandangan. Advances in Social Science. Educational and Humanities research, 272274.

Sujiono, Y. (2013). The Basic Concept of Early Childhood Education. Jakarta: PT Indeks.

Sunde, K., Furnes, B., \& Lundetrae, K. (2020). Does Introducing the Letters faster Boost the Development of Children's Letter Knowledge, Word Reading and Spelling in the First Year of School? Scientific Studies of Reading, 24(2), 141-158.

Suriansyah, A., \& Aslamiah. (2011). Education Foundation. Banjarmasin: Comdes.
Suriansyah, A., \& Aslamiah. (2011). Early Childhood Learning Strategy. Banjarmasin: Comdes

Suriansyah, A., Aslamiah, Noorhafizah, \& Sulaiman. (2009). Strategi Pembelajaran. Banjarmasin: Universitas Lambung Mangkurat.

Ulla, M. B., \& Winitkun, D. (2017). Thai learners' linguistic needs and language skills: Implications for curriculum development. International Journal of Instruction, 10(4), 203-220.

Young, S. (2008). Lullaby light shows: Everyday musical experience among under-two-year-olds. International Journal of Music Education, 26(1), 33-46.

Zhai, J., Jocz, J. A., \& Tan, A. L. (2014). Am I lLike a Scientist?: Primary children's image of doing science in school. International Journal of Science Education, 36(4), 553-576. 